\title{
Effect of Heat Treatment on Microstructure Evolution of X38CrMoV5-1 Hot-Work Tool Steel Produced by L-PBF
}

\author{
GREGORIO CARASI, BOSCO YU, ESTHER HUTTEN, HATEM ZUROB, \\ RICCARDO CASATI, and MAURIZIO VEDANI
}

\begin{abstract}
The X38CrMoV5-1 hot-work tool steel produced by laser powder bed fusion was investigated to assess the effect of quenching and tempering and direct tempering on the as-built microstructure. After the printing process, the material microstructure appeared to be characterized by a fine cellular network consisting of $\gamma$-Fe cell boundaries and $\alpha^{\prime}$-Fe cores. Scheil-Gulliver curves, $\mathrm{X}$-ray diffraction patterns, and transmission electron microscopy images suggested a transformation of the inner core zone from $\delta$-Fe to $\alpha^{\prime}$-Fe through $\gamma$-Fe. Air quenching promoted the transition of the solidification structure into a fully martensitic microstructure. Both as-built and quenched samples revealed the presence of manganese oxides and vanadium carbonitrides forming core-shell structures. After tempering, starting from as-built and from quenched condition, a dispersion of nano-sized $\mathrm{V}$ and $\mathrm{Cr}$-rich second phases was formed in the microstructure, achieving hardness values comparable to those obtained by the same alloy produced by conventional methods. The specimen tempered directly after the laser powder bed fusion process showed a hardness peak shifted towards higher temperatures compared to the conventionally tempered sample.
\end{abstract}

https://doi.org/10.1007/s11661-021-06248-y

(c) The Author(s) 2021

\section{INTRODUCTION}

IN recent years, the development of additive manufacturing (AM) has been driven by the need to combine just-in-time production of customized components with the potential to meet environmental requirements by reducing material waste, energy consumption, and overall carbon footprint. ${ }^{[1]}$ The most important and appreciated advantage of AM is the wide design freedom that allows the production of parts with complex shapes that are difficult to manufacture with conventional technologies.

Laser powder bed fusion (L-PBF), also known as selective laser melting, is the main reference AM process for metals. Several studies conducted in the last few years have assessed the correct processability of a wide variety of materials and the concrete possibility to produce fully dense components using L-PBF

GREGORIO CARASI, RICCARDO CASATI, and MAURIZIO VEDANI are Department of Mechanical Engineering, Politecnico di Milano, Via G. La Masa 34, 20156 Milano, Italy. Contact e-mail: riccardo.casati@polimi.it BOSCO YU, ESTHER HUTTEN, and HATEM ZUROB are with the Department of Materials Science and Engineering, McMaster University, 1280 Main Street West, Hamilton, ON L8S 4L7, Canada

Manuscript submitted October 6, 2020, accepted March 15, 2021.

Article published online April 11, 2021 technology. In particular, nickel alloys, ${ }^{[2]}$ aluminum alloys, ${ }^{[3,4]}$ cobalt alloys, ${ }^{[5]}$ titanium alloys, ${ }^{[6]}$ and stainless steels ${ }^{[7,8]}$ have already been the object of extensive research. The intense heating and cooling rates induced by the interaction between the high-power laser beam and the metal powder bed are the main factors that affect the solidification microstructure of materials processed by L-PBF. ${ }^{[9]}$ In most of the alloys investigated, these extreme thermal conditions generate unique microstructures characterized by fine cellular networks that are responsible for the peculiar mechanical properties of parts. ${ }^{[3-5,7,8]}$ The possibility to use L-PBF to produce customized complex-shape parts has recently attracted the attention of mold and die makers to produce tools featuring conformal cooling channels, thus, ensuring uniform heat extraction from parts, shorter cooling rates, lower residual stresses, and longer thermal fatigue life for tools. ${ }^{[10]}$

Steel grades for hot-work applications, which belong to the group $\mathrm{H}$ of the AISI designation system, share common characteristics such as high strength and wear resistance at high working temperatures, capability to resist to repeated mechanical and thermal loadings, geometrical stability during heat treatment, and good machinability. Large carbides mainly contribute to wear resistance, whereas smaller carbides enhance the yield strength by hindering dislocation movement. Chromium 
hot-work tool steels, which contain nominally $5 \mathrm{wt}$ pct of $\mathrm{Cr}$ and significant amounts of other elements including $\mathrm{Si}, \mathrm{Mo}$, and $\mathrm{V}$ are widely used for forging and die-casting applications. ${ }^{[1,12]}$

Despite the rising interest in L-PBF technology, only few steels for tooling applications have been tested in order to assess their processability. Most of the previous works focused on maraging ${ }^{[13,14]}$ and high-speed steels, ${ }^{[15,16]}$ and a few recent studies also investigated hot-work tool steels. Some researches on H13 steel grade investigated the effect of processing parameters, such as laser power, scan speed, hatch spacing, ${ }^{[17-19]}$ and platform temperature ${ }^{[20]}$ on material properties, in terms of relative density, microstructure, and mechanical behavior, validating the possibility to produce fully dense crack-free parts by L-PBF. Further studies evaluated the effect of heat treatments ${ }^{[17,18,21]}$ and hot isostatic pressing $^{[22,23]}$ on microstructural features. Some of the authors of the present paper characterized the microstructure and mechanical properties of $\mathrm{H} 11$ hotwork tool steel and a leaner version of the same alloy processed by L-PBF as a function of specific heat treatment conditions, confirming the possibility to perform direct tempering right after L-PBF consolidation, thus, without performing any prior solution annealing, to achieve satisfactory hardness values. ${ }^{[21]}$

Martensitic hardenable tool steels exhibit complex behavior and microstructures when processed by L-PBF, due to the peculiar thermal history experienced during processing. An in-depth understanding of the mechanisms regulating the microstructure evolution of material during laser processing and post-processing heat treatments is crucial to tailor material properties for tooling applications. Thus, the aim of the present study is to comprehensively investigate the evolution of the microstructure of the AISI H11 hot-work tool steel (equivalent to EN X38CrMoV5-1 grade) processed by L-PBF. To this purpose, the effect of quenching and tempering and direct tempering on the as-built microstructure was evaluated by field emission scanning electron microscopy (FE-SEM), X-ray diffraction (XRD), differential scanning calorimetry (DSC), and transmission electron microscopy (TEM). The phase formation during solidification was additionally simulated by Thermo-Calc under Scheil-Gulliver hypotheses to improve the understanding of experimental results.

\section{MATERIALS AND EXPERIMENTAL METHODS}

Gas atomized X38CrMoV5-1 hot-work tool steel powder $\left(D_{10}=22.75 \mu \mathrm{m}, \quad D_{50}=37.64 \mu \mathrm{m}\right.$, $\left.D_{90}=60.51 \mu \mathrm{m}\right)$, supplied by Cogne Acciai Speciali $\mathrm{SpA}$, was used for this study. The compositions of the powder feedstock are reported in Table I.

Cubic samples $\left(10 \times 10 \times 10 \mathrm{~mm}^{3}\right)$ were produced by L-PBF using a Renishaw AM250 system equipped with a reduced build volume device with a maximum build dimension of $78 \times 78 \times 55 \mathrm{~mm}^{3}$. The system operates with a $200 \mathrm{~W}$ single-mode fiber pulsed laser with estimated beam diameter at focal point of $75 \mu \mathrm{m}$. Laser melting is performed by discrete and partially overlapped laser spots in a sealed chamber under $\mathrm{Ar}$ atmosphere. No preheating was applied to the build plate. Optimization of parameters was performed based on a Design of Experiment approach. Point distance and hatch distance were varied in order to obtain the highest possible relative density. The best combination of parameters is reported in Table II and was used to print all the samples. Samples were produced using a meander scanning strategy and the scanning direction was rotated by $67 \mathrm{deg}$ after each layer completion.

DSC analyses were performed in Ar atmosphere using a heating rate of $10{ }^{\circ} \mathrm{C} / \mathrm{min}$ by Setaram Labsys calorimeter.

In order to find the optimal heat treatment conditions, air quenching and tempering at different temperatures levels, selected around the temperature suggested by the ASTM standard specification (Table III) ${ }^{[24]}$ were performed on the cubic samples. Air quenching was, thus, performed after holding the specimens for 5 minutes at $960{ }^{\circ} \mathrm{C}, 1010{ }^{\circ} \mathrm{C}$, and $1060{ }^{\circ} \mathrm{C}$. The holding time of 5 minutes was defined after preliminary tests not reported in this paper. Tempering was performed on both quenched and as-built samples at $450{ }^{\circ} \mathrm{C}, 500{ }^{\circ} \mathrm{C}$, $550{ }^{\circ} \mathrm{C}$ and $600{ }^{\circ} \mathrm{C}$ for 2 hours. Hardness of samples treated to different conditions was determined by means of Vickers micro-hardness tests applying $1 \mathrm{~kg}_{\mathrm{F}}$.

Microstructural observations were conducted with a Zeiss Sigma 500 scanning electron microscope (FE-SEM), equipped with in-lens secondary electron detector (SE), energy dispersive X-ray detector (EDX), and backscattered electron detector (BSE). For FE-SEM analysis, all samples were mounted, grinded, and polished and etched in Nital 2 pct reagent ( 2 vol pct nitric acid in ethanol). Transmission electron microscopy (TEM) was carried out by mounting materials into epoxy holders and then carefully grinding them to $\sim 100 \mu \mathrm{m}$ thin foils. Disks with a diameter of $3 \mathrm{~mm}$ were then punched out and dimpled using a $0.1 \mu \mathrm{m}$ cubic boron nitride compound, followed by jet polishing in 5 pct perchloric and 95 pct ethanol. The microstructures were then analyzed in a TEM (JEOL-2010F microscope) using both bright-field and dark-field imaging at $200 \mathrm{kV}$. Additional electron energy loss spectroscopy (EELS) imaging was carried out in STEM mode with a probe size of $1 \mathrm{~nm}$. The EELS maps were acquired with a pixel size of $1.5 \mathrm{~nm}$ and exposure time of 0.01 seconds.

$\mathrm{X}$-ray diffraction (XRD) experiments were carried out with a Rigaku SmartLab SE multipurpose X-ray diffractometer, which uses copper as a source of radiation with $\mathrm{Cu}_{\alpha 1}$ of $1.54060 \AA$ and $\mathrm{Cu}_{\alpha 2}$ of 1.54439 $\AA$ operating at $40 \mathrm{kV}$ and $40 \mathrm{~mA}$. All diffraction patterns were collected in Bragg-Brentano geometry at a scan rate of $1 \mathrm{deg} / \mathrm{min}$ and step size of $0.02 \mathrm{deg}$ with diffraction angle $2 \theta$ varying from 30 to $100 \mathrm{deg}$. To achieve better pattern quality and avoid undesired preferential orientation effects, samples were rotated at $60 \mathrm{rpm}$ during the tests. The software QUALX2.0 ${ }^{[25]}$ was used for phase identification. Rietveld refinement for quantitative phase analysis was carried out using FullProf Suite software. ${ }^{[26]}$ 
Table I. Chemical Composition (Weight Fraction, Pct) of the Investigated X38CrMoV5-1 Steel Powder

\begin{tabular}{lcccccccc}
\hline $\mathrm{C}$ & $\mathrm{Cr}$ & $\mathrm{Mo}$ & $\mathrm{Si}$ & $\mathrm{V}$ & $\mathrm{Mn}$ & $\mathrm{P}$ & $\mathrm{S}$ & $\mathrm{Fe}$ \\
\hline 0.34 & 5.15 & 1.24 & 0.93 & 0.49 & 0.37 & 0.006 & 0.005 & bal. \\
\hline
\end{tabular}

Table II. L-PBF Parameters Selected for the Production of the Investigated Samples

\begin{tabular}{ll}
\hline Laser Power, $P(\mathrm{~W})$ & 200 \\
Exposure Time, $t(\mu \mathrm{s})$ & 80 \\
Point Distance, $d_{\mathrm{P}}(\mu \mathrm{m})$ & 40 \\
Hatch Distance, $d_{\mathrm{H}}(\mu \mathrm{m})$ & 80 \\
Layer Thickness, $h(\mu \mathrm{m})$ & 40 \\
Focal Point, $\Delta z(\mathrm{~mm})$ (Above the Powder Bed) & 1 \\
\hline
\end{tabular}

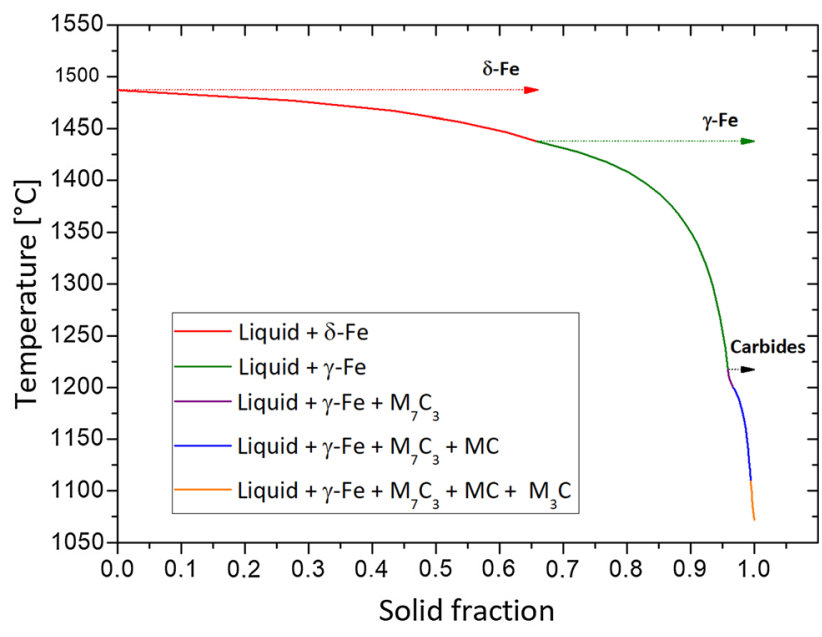

Fig. 1-Scheil-Gulliver simulation of the solidification sequence of the X38CrMoV5-1 steel.

Table III. ASTM Standard Specifications for H11 Heat Treatments ${ }^{[24]}$

\begin{tabular}{lccc}
\hline Austenitizing Temperature $\left({ }^{\circ} \mathrm{C}\right)$ & Austenitizing Time (Min) & Tempering Temperature $\left({ }^{\circ} \mathrm{C}\right)$ & Tempering Time (Min) \\
\hline 1010 & $5-15$ & 552 & 120 \\
\hline
\end{tabular}

The solidification sequence of X38CrMoV5-1 was simulated with the Scheil-Gulliver method using Thermo-Calc software and TCFE (TCS Steel and Fe-alloys) database. The phases selected for this simulation were liquid, $\alpha-\mathrm{FE}$ (bcc), $\gamma$-Fe (fcc), $\mathrm{M}_{7} \mathrm{C}_{3}$, and $\mathrm{M}_{3} \mathrm{C}, \mathrm{MC}$. For the purpose of this simulation, the starting temperature was set at $1500{ }^{\circ} \mathrm{C}$ while the value of 0.01 for the fraction of liquid phase was used as terminating condition.

\section{RESULTS}

The Scheil-Gulliver simulation was performed to assess the expected solidification phase sequence of the X38CrMoV5-1 steel. According to the results that are shown in Figure 1, about 66 wt pct of the material solidifies as $\delta$-Fe, while the rest solidifies as $\gamma$-Fe and carbides. Moreover, three main types of carbides are formed upon solidification: $\mathrm{M}_{7} \mathrm{C}_{3}$, a hexagonal $\mathrm{Cr}$-rich carbide, MC, a face-centered cubic V-rich monocarbide, and $\mathrm{M}_{3} \mathrm{C}$, an orthorhombic carbide based on the cementite crystal structure $\left(\mathrm{Fe}_{3} \mathrm{C}\right) .{ }^{[12]}$

Optical and FE-SEM micrographs of the cross section parallel to the building direction were collected on as-built X38CrMoV5-1 samples produced by L-PBF, in order to investigate the solidification structure. The typical fish-scale structure is highlighted in Figure 2(a), showing the profiles of the distinct melt pools and demonstrating the absence of cracks or other solidification defects. Moreover, etching revealed the presence of two different phases in secondary electron contrast. A bright-contrast phase encloses a darker phase in a cell-like structure, as shown in Figure 2(c).

As shown in Figure 2, the size of solidification cells ranges between 0.5 and $1 \mu \mathrm{m}$, while the inter-cellular region, presumably made of $\gamma-\mathrm{Fe},{ }^{[17]}$ has a thickness smaller than $200 \mathrm{~nm}$. Cells can also exhibit elongated shapes depending on their orientation and their position in the solidified melt pools. It has been shown in previous works ${ }^{[7]}$ that colonies of elongated cells with similar aspect ratio and crystallographic orientation grow epitaxially along thermal gradients to form grains. At high magnifications (see Figure 2(d)), the core cell results possibly made of martensite, tempered martensite or bainite; indeed small microstructure features appear in the cells but cannot be identified confidently.

Since the size of the features forming the material microstructure is relatively small, the analysis of the chemical composition by SEM-EDX could not be carried out with high accuracy. Nevertheless, chemical microanalysis results obtained from different areas of the cell structure, presented in Table IV, show an inter-cellular region enriched in alloying elements $(\mathrm{Cr}$, $\mathrm{Mo}, \mathrm{V}$, and $\mathrm{Si}$ ) with respect to the core region. Carbon content is not included in the quantitative analysis, but it is also expected to increase at cell boundaries.

TEM and EELS analyses were carried out in order to further investigate steel microstructure. TEM images of the as-built sample are presented in Figure 3 and show the presence of elongated laths, typical microstructural features of the martensitic phase, which indicate that the core of the cells is mainly constituted by $\alpha^{\prime}-\mathrm{Fe}$. This is in good agreement with previous works ${ }^{[27,28]}$ which show 

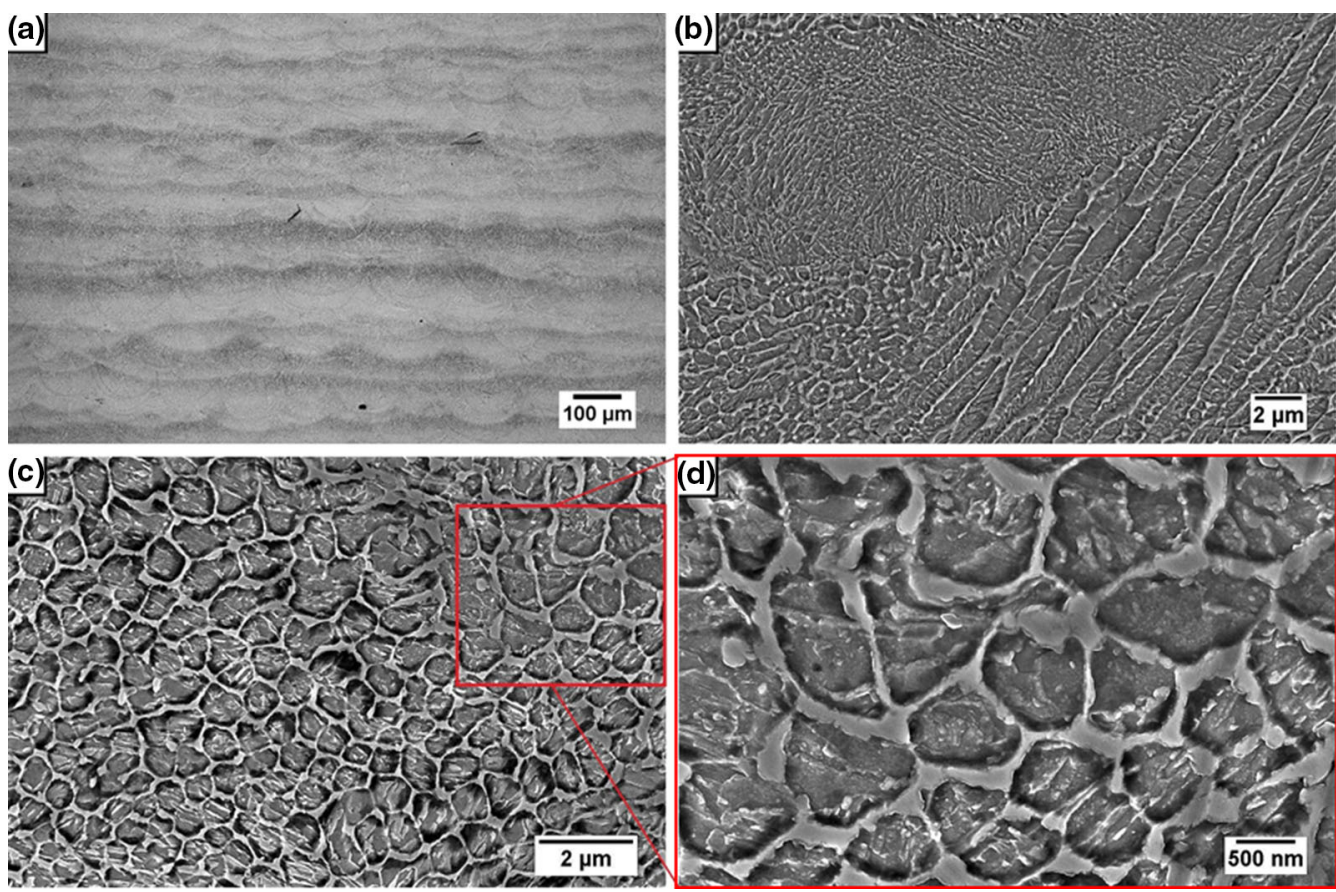

Fig. 2-Optical micrograph (a) and FE-SEM images at (b) low, $(c)$ mid, and (d) high magnification of the as-built sample microstructure.

the presence of a martensitic microstructure with retained austenite in $\mathrm{H} 13$ produced by L-PBF.

EELS analysis reveals the presence of tiny second phases made up of core-shell structures, in which vanadium carbonitride shells grow preferentially from manganese oxide cores (Figure 4).

The DSC curve related to the as-built sample is reported in Figure 5. It reveals the presence four peaks related to the phase transformations pointed out with letters, from A to D. The first peak (A) is broad and exothermic, and it is associated to carbide precipitation. ${ }^{[21]}$ It is followed by an endothermic peak (B) which is associated to the ferromagnetic to paramagnetic transformation at the Curie point, while the second endothermic peak (C) is due to the transformation into $\gamma-\mathrm{Fe}^{\left[{ }^{[29]}\right.}$ Lastly, the broad and multiple set of endothermic peaks (D) is assumed to be related to the dissolution of different carbide species.

Starting from the as-built condition, two thermal treatment strategies were investigated, namely direct tempering and quench and tempering. All hardness results of as-built, quenched, and tempered materials are summarized in the diagrams of Figure 6. Air quenching was performed after holding the specimens for 5 minutes at three different temperature levels, namely $960{ }^{\circ} \mathrm{C}$, $1010{ }^{\circ} \mathrm{C}$, and $1060{ }^{\circ} \mathrm{C}$. It resulted that quenching from $1010{ }^{\circ} \mathrm{C}$ leads to highest material hardness of $570.1 \pm 5.1 \mathrm{HV}$. Tempering was then performed for 2 hours at temperatures ranging between $450{ }^{\circ} \mathrm{C}$ and $600{ }^{\circ} \mathrm{C}$. Considering the conditions providing the highest hardness, it can be stated that the specimen directly tempered at $550{ }^{\circ} \mathrm{C}$ from the as-built condition showed a hardness of $557.2 \pm 1.7 \mathrm{HV}$ while that tempered at
$500{ }^{\circ} \mathrm{C}$ after air quenching showed a hardness of $560.4 \pm 1.6 \mathrm{HV}$.

The XRD patterns of the as-built and the heat-treated samples are shown in Figure 7. The result about the as-built sample shows the reflections of two main phases, namely $\gamma$-Fe and a $\alpha / \alpha^{\prime}-\mathrm{Fe}$. Due to the relatively low content of carbon, no apparent splitting or asymmetries of the ferrite reflection could be observed, and no distinction could be made between $\alpha$-Fe and $\alpha^{\prime}$-Fe phases. Considering the results of the Scheil-Gulliver simulation (Figure 1), which indicates the formation of $\gamma$-Fe at the end of solidification, and thus at cell boundary, it is supposed that the $\gamma$-phase could correspond to the inter-cellular phase identified in Figure 2. All the heat-treated samples revealed no $\gamma$-Fe peaks; therefore, the amount of austenite is below the sensitivity limit of the instrument (around $2 \mathrm{pct}$ ). Similarly, no carbide phases were detected by the XRD analysis due to their small volume fraction.

According to the results of Rietveld refinement presented in Table $\mathrm{V}$, the as-built specimen contains 76.7 pct of $\alpha / \alpha^{\prime}-\mathrm{Fe}$ and 23.3 pct of $\gamma$-Fe.

After tempering at $550{ }^{\circ} \mathrm{C}$ of the as-built sample, the characteristic cell-like structure has partially dissolved (Figure 8). The inter-cellular austenitic region looks visibly thinner while the darker ferritic phase appears to have grown. Thus, the network opens up generating larger crystallites due to the $\gamma \rightarrow \alpha+$ carbides transformation. Small carbides are hardly distinguishable by FE-SEM analysis. At high magnifications, the core of cells shows small microstructure features hardly identifiable. 
Table IV. Chemical Composition in Wt Pct of the Core and of the Boundary Regions

\begin{tabular}{|c|c|c|c|c|c|c|}
\hline \multicolumn{7}{|c|}{ Mass Fraction (Wt Pct) $( \pm \sigma)$} \\
\hline & $\mathrm{Cr}$ & Mo & $\mathrm{Si}$ & V & $\mathrm{Mn}$ & $\mathrm{Fe}$ \\
\hline Core & $4.8( \pm 0.5)$ & $1.7( \pm 0.4)$ & $1.3( \pm 0.1)$ & $0.7( \pm 0.3)$ & $0.6( \pm 0.5)$ & bal. \\
\hline Inter-Cellular Region & $8.5( \pm 1.0)$ & $4.4( \pm 0.9)$ & $2.0( \pm 0.3)$ & $1.9( \pm 0.6)$ & $0.7( \pm 0.6)$ & bal. \\
\hline
\end{tabular}
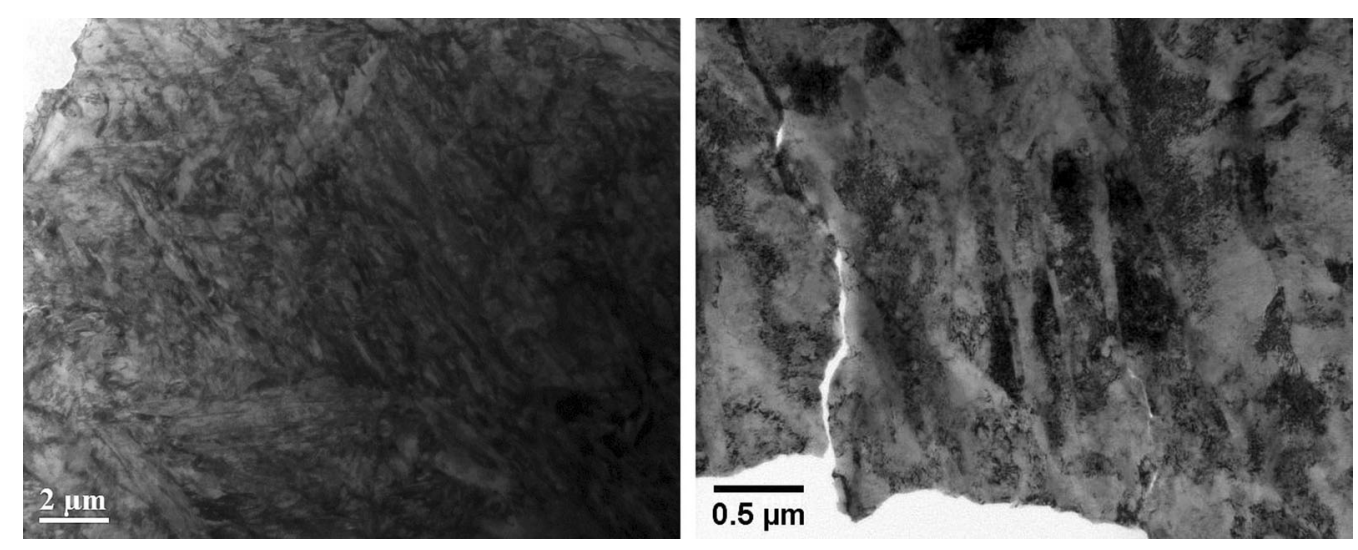

Fig. 3-Bright-field TEM image at low magnification (left) and mid magnification (right) of the as-built sample.

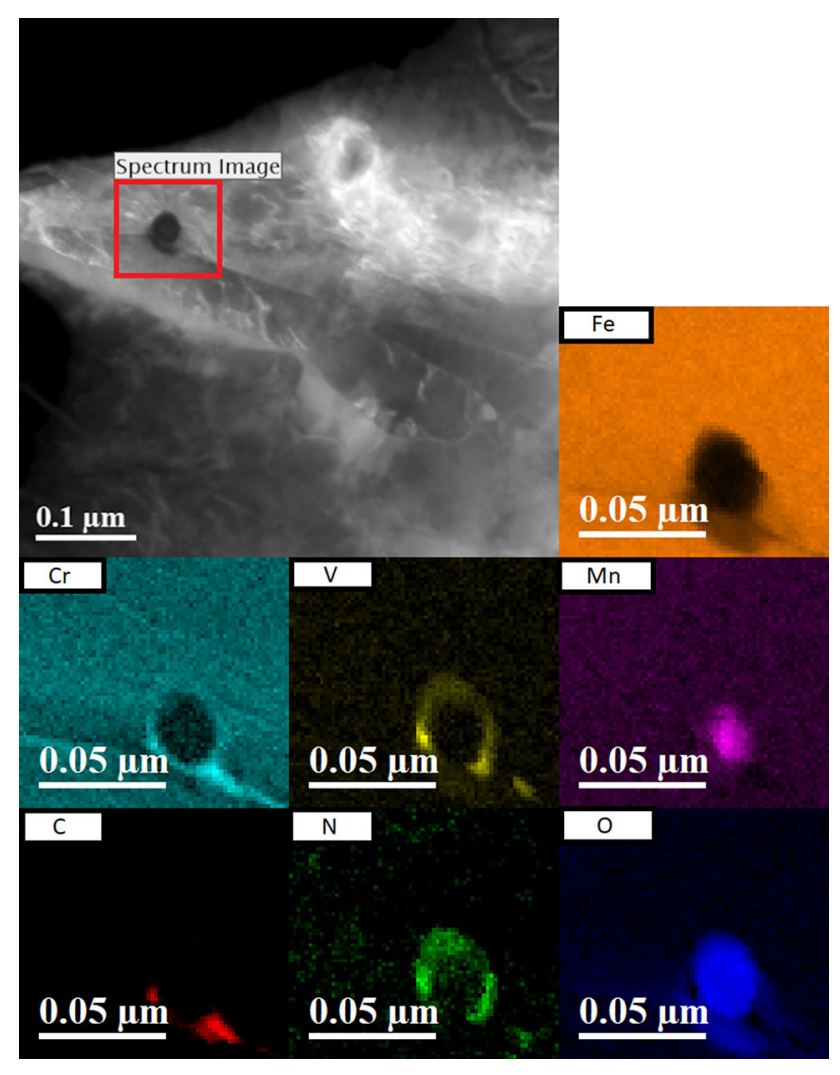

Fig. 4 - Survey image and EELS elemental mapping of the as-built sample.

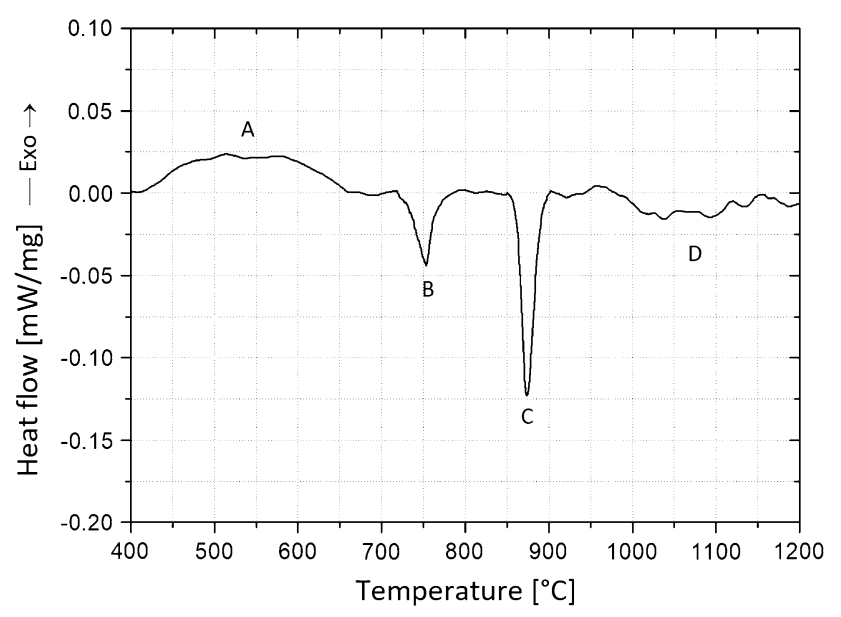

Fig. 5-DSC curve related to the as-built sample recorded at $10^{\circ} \mathrm{C} /$ min.

TEM images presented in Figure 9 show that, directly tempered specimens are characterized by tempered martensite with sub-grain cell structures.

Directly tempered samples feature higher concentration of fine Cr-rich and V-rich nano-carbides, as shown by EELS analysis results showed in Figure 10, which confirms the effective precipitation of carbides during tempering. This is in good agreement with the DSC curve of the as-built material shown in Figure 5 and with the increase in material hardness highlighted in the diagram of Figure 6.

After air quenching from $1010^{\circ} \mathrm{C}$, both FE-SEM (Figure 11) and TEM images (Figure 12) show that the solidification cellular structure is lost, revealing a full martensitic structure. Moreover, FE-SEM images reveal 

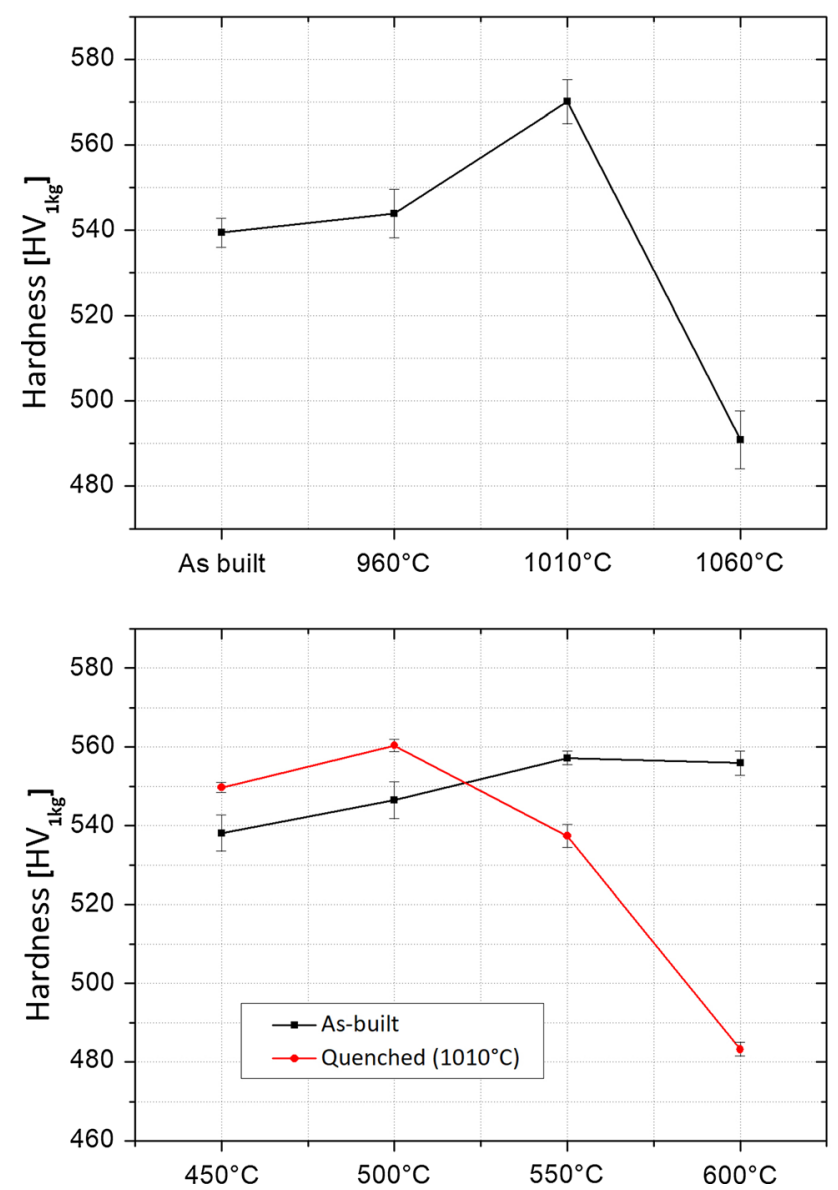

Fig. 6-Vickers hardness numbers of X38CrMoV5-1 samples as a function of the quenching temperature (top) and after tempering at different temperatures (bottom).

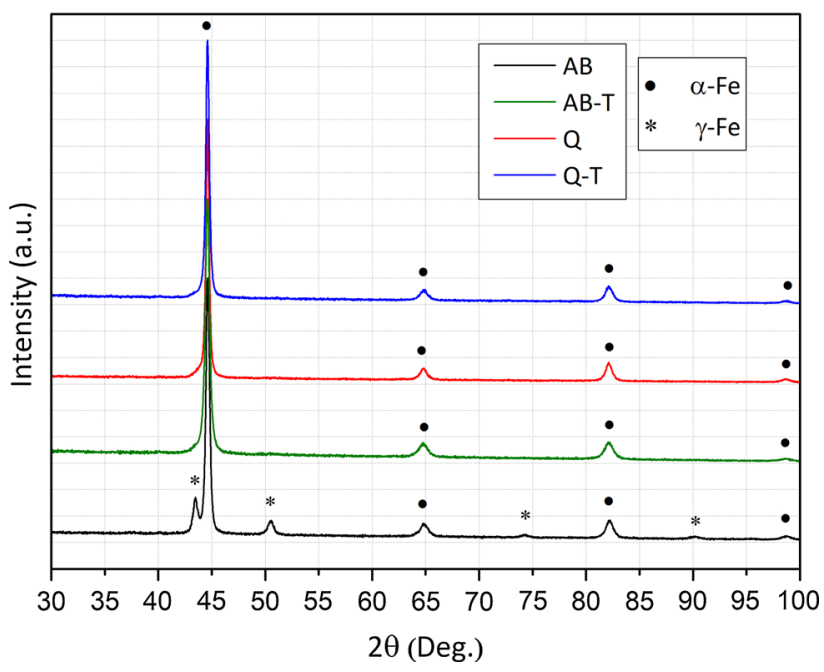

Fig. 7-XRD pattern comparison between the as-built and the heat-treated samples.

a dispersion of particles with mean size ranging from 50 to $100 \mathrm{~nm}$, corresponding probably to carbides that did not dissolved during austenitization and oxides formed during L-PBF or gas atomization. SEM-EDX analysis revealed a higher concentration of $\mathrm{V}$ in the spherical particles, as shown in Table VI. The estimated values are meant to be indicative only, due to the small size of the particles. EELS analysis presented in Figure 13 shows nanometric $\mathrm{V}$ carbonitrides dispersed in the matrix, growing next to $\mathrm{Mn}$ oxides and occasionally forming core-shell structures as those found in the as-built samples.

In addition to the expected tempered martensite microstructure revealed by FE-SEM (Figure 14) and TEM images (Figure 15), the quenched samples, after tempering at $500{ }^{\circ} \mathrm{C}$, are characterized by the presence of spherical particles, with mean diameter of about 50 $\mathrm{nm}$, homogeneously dispersed in the material, as highlighted in Figure 14(c). Due to their small size, SEM-EDX chemical microanalysis could not be performed to reveal their composition. FE-SEM revealed also the presence of bigger particles, as pointed out by the arrow in Figure 14(b) that are characterized by an elongated irregular shape and a mean particle size of about 200-400 nm. SEM-EDX chemical microanalysis shows that such particles are rich in $\mathrm{Cr}$ (see Table VII).

EELS analysis presented in Figure 16 confirms the presence of a homogeneous dispersion of nano-sized Vand $\mathrm{Cr}$-rich nanoparticles in the microstructure.

\section{DISCUSSION}

X38CrMoV5-1 (AISI H11) tool steel produced by L-PBF is characterized by a peculiar microstructure constituted of two main phases organized in a fine network of cell-like structures in which the $\gamma$-Fe phase encloses $\alpha / \alpha^{\prime}-\mathrm{Fe}$ cores (Figure 2). The solidification of $\delta$-Fe leads to a progressive element enrichment in the remaining melt that solidifies as $\gamma$-Fe (Figure 1). The results of the chemical microanalysis performed on different spots of the cell structure (Table IV) indicate that the $\gamma$-Fe inter-cellular region is enriched in alloying elements with respect to the $\alpha / \alpha^{\prime}-\mathrm{Fe}$ core zone. The higher element concentration is responsible of the decrease in $M_{\mathrm{s}}$ and stabilization of the austenite.

After solidification, $\delta$-Fe can either transform directly into $\alpha$-Fe or into $\alpha^{\prime}-\mathrm{Fe}$ through an intermediate $\gamma$-Fe phase with lower amount of alloying elements compared to the inter-cellular $\gamma$-Fe. ${ }^{[17]}$ The distinction between body-centered cubic and face-centered cubic Fe phases when $\mathrm{C}$ content is relatively low, as in the present case, is not possible by XRD. Nevertheless, TEM images shown in Figure 3 reveal a microstructure characterized mainly by elongated lath typical of the martensite, ${ }^{[27]}$ suggesting a transformation from $\delta$-Fe into $\alpha^{\prime}$-Fe through $\gamma$-Fe.

The amount of $\alpha / \alpha^{\prime}-\mathrm{Fe}$ at room temperature estimated by the Rietveld refinement is about 77 pct (Table V), and it is slightly higher than the amount of $\delta$-Fe calculated by Scheil-Gulliver simulation, of about 66 pct (Figure 1). This gap could be ascribed to the intrinsic heat treatment effect of the L-PBF process in the already solidified layers, ${ }^{[9]}$ which would promote the transformation of a share of the $\gamma$-Fe into $\alpha$-Fe and carbides. 
EELS analysis (Figure 4) revealed a dispersion of manganese oxides and vanadium carbonitrides in the material. Oxide particles are commonly found on surfaces of feedstock powder particles and can be also found in the final L-PBF part. ${ }^{[30]}$ Moreover, due to its high affinity to oxygen, manganese might also form additional oxides during laser processing. ${ }^{[31]}$

Table V. Relative Amount of Ferrite and Austenite by Rietveld Refinement

\begin{tabular}{lcccc}
\hline$\alpha / \alpha^{\prime}-\mathrm{Fe}(\mathrm{Wt} \mathrm{Pct})$ & $\gamma$-Fe (Wt Pct) & $R_{\mathrm{wp}}$ & $R_{\exp }$ & $\chi^{2}$ \\
\hline 76.67 & 23.3 & 10.9 & 8.93 & 1.22 \\
\hline
\end{tabular}

During direct tempering, the cell-like microstructure partially dissolves. FE-SEM analysis (Figure 8) shows that the austenitic inter-cellular region is noticeably thinner than those found in the as-built steel, due to the transformation from $\gamma$-Fe to equilibrium constituents. EELS analysis (Figure 10) shows a dispersion of nano-sized $\mathrm{V}$ - and $\mathrm{Cr}$-rich second phases. This result is consistent with DSC curve of the as-built sample, which shows a wide exothermic peak below $650{ }^{\circ} \mathrm{C}$ related to carbide precipitation (Figure 5) and with the increased material hardness (Figure 6), validating the capability of H11 tool steel processed by L-PBF to promote secondary hardening during the tempering right after the printing process.

The FE-SEM images of Figure 11 show that the cellular microstructure of the as-built sample is completely lost after quenching and it is replaced by a fully
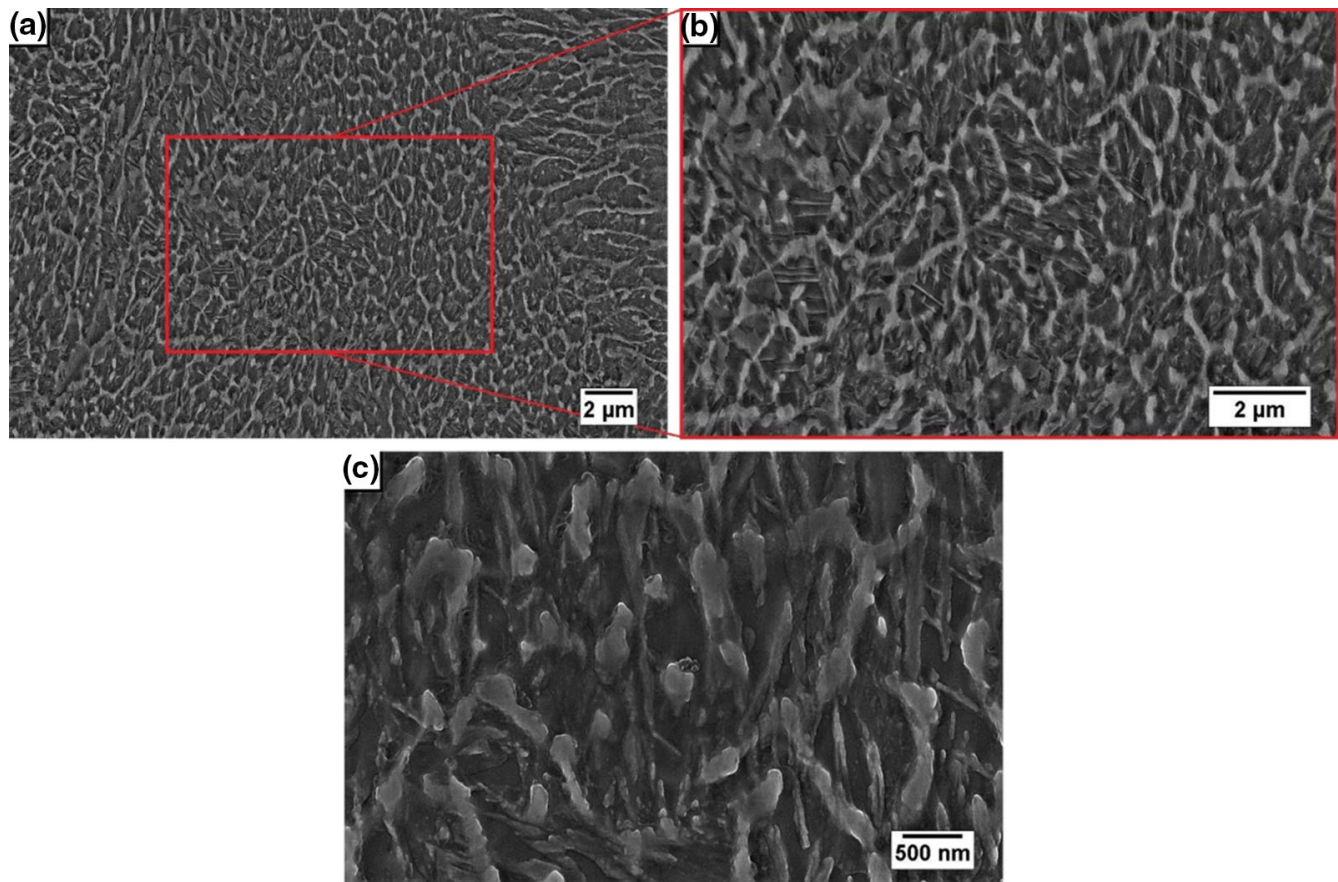

Fig. 8-FE-SEM images of the microstructure of directly tempered at $550{ }^{\circ} \mathrm{C}$ sample at $(a)$ low, $(b)$ mid, and $(c)$ high magnification.
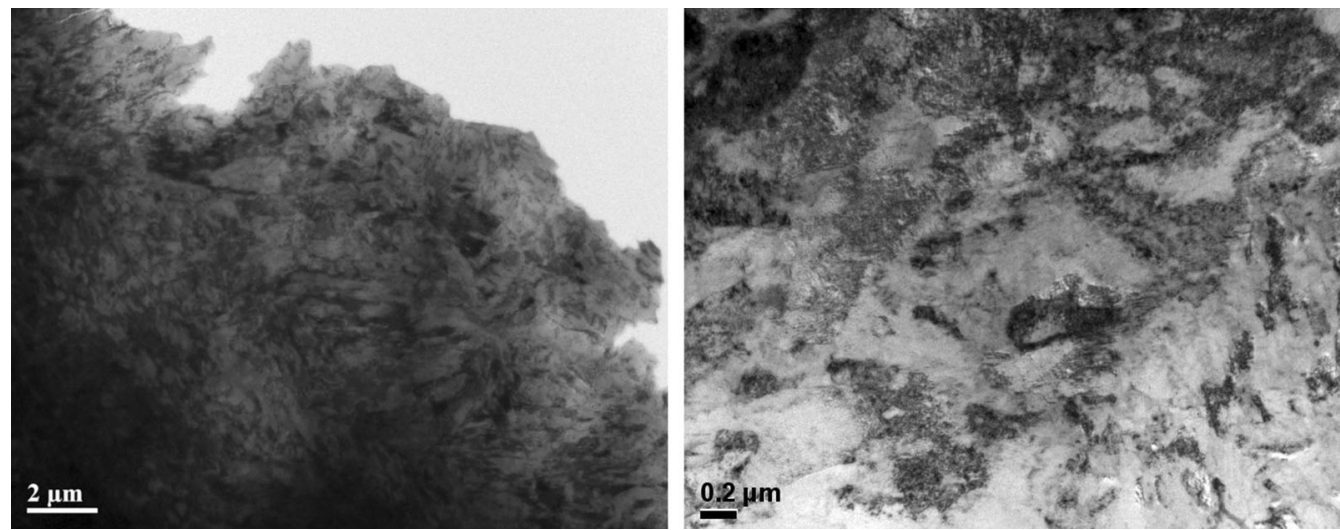

Fig. 9-Bright-field TEM image at low magnification (left) and mid magnification (right) of the as-built and tempered sample. 


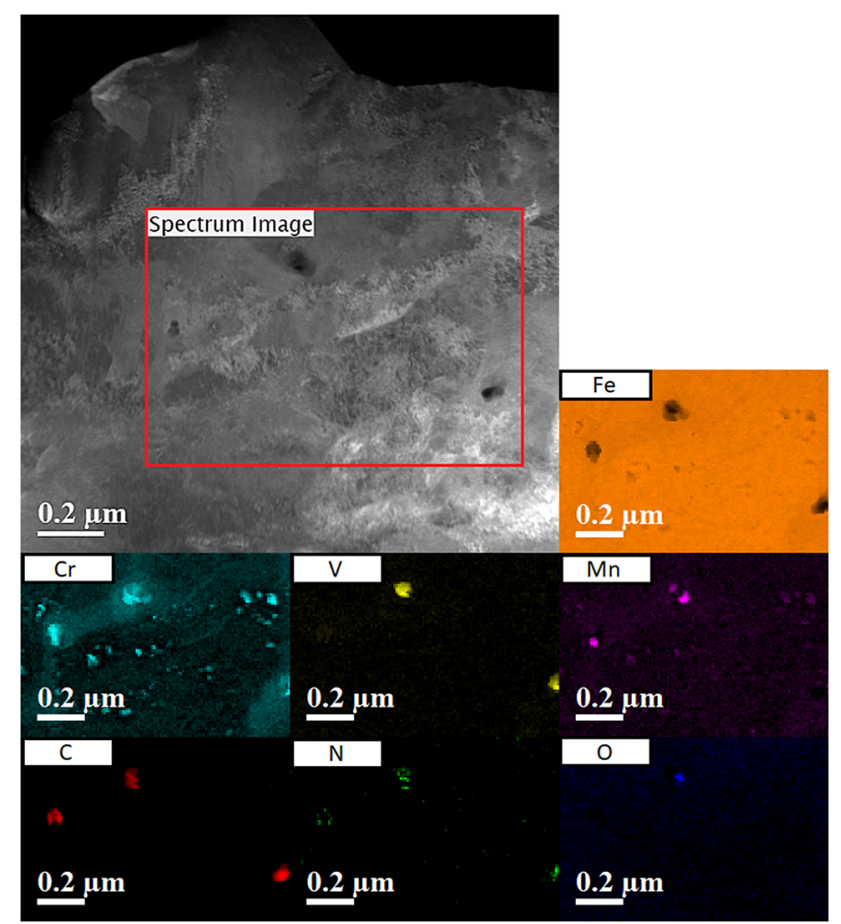

Fig. 10 - Survey image and EELS elemental mapping of the as-built and tempered sample. martensitic microstructure. Such micrographs also reveal the occurrence of small spherical second phases characterized by high vanadium content (Table VI). This suggests that $\mathrm{V}$ carbonitrides, already present in the as-built material before quenching (Figure 4), are not completely dissolved during austenitization at $1010^{\circ} \mathrm{C}$. TEM images are in good agreement with the FE-SEM micrographs revealing a fully martensitic microstructure (Figure 12). Moreover, EELS analysis (Figure 13) confirms the presence of $\mathrm{V}$-rich particles and reveals the occurrence of core-shell structures similar to those found in the as-built microstructure.

FE-SEM and TEM images (Figures 14 and 15) of quenched and tempered sample showed, as expected, a tempered martensitic structure. The effect of the tempering is highlighted by a fine distribution of nano-particles (Figure 14(c)), similar to those found in the direct tempered steel. These second phases, according to EELS analysis (Figure 16), are fine mixed chromium and vanadium carbides. Figure 14(b) shows that tempering can also lead to the precipitation of bigger second phases with high concentration of $\mathrm{Cr}$, likely carbides.

The effect of tempering on the steel hardness is shown in the diagram in Figure 6. The samples tempered from the as-build and from quenched conditions show similar hardness, namely 557.2 $\mathrm{HV}$ and $560.4 \mathrm{HV}$, respectively.
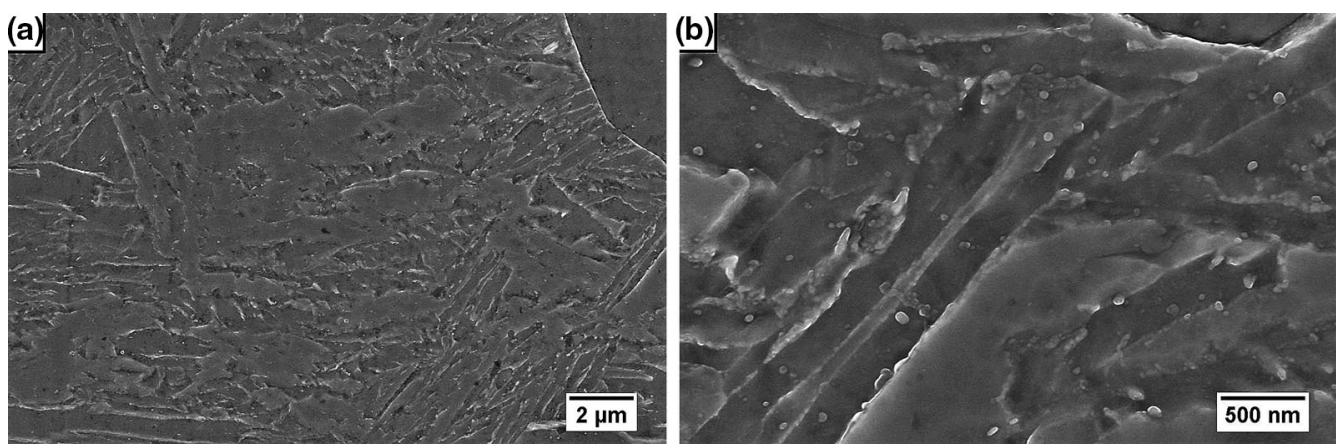

Fig. 11-FE-SEM images of the quenched sample microstructure at (a) low and (b) high magnification.
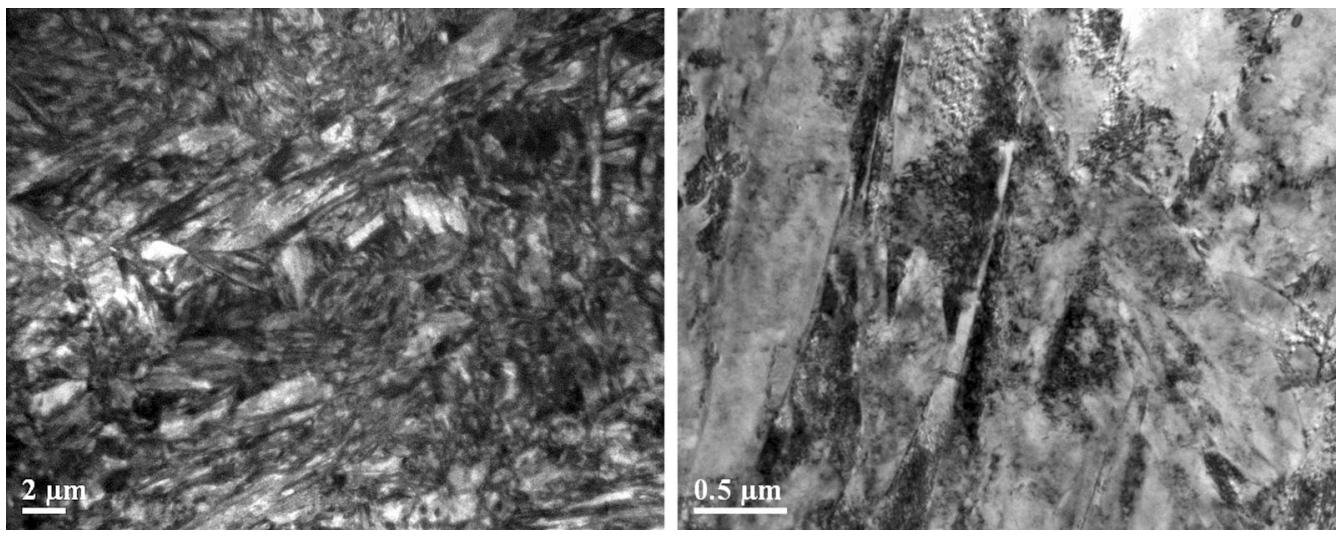

Fig. 12-Bright-field TEM image at low magnification (left) and mid magnification (right) of the quenched sample. 
Table VI. Chemical Composition in Wt Pct of a V-Rich Particle Compared to the Matrix

\begin{tabular}{lcccccc}
\hline \multicolumn{7}{c}{ Mass Fraction $($ Wt Pct $)( \pm \sigma)$} \\
\hline Particle & Cr & Mo & Si & V & Mn & Fe \\
Matrix & $5.7( \pm 1.1)$ & $2.3( \pm 0.3)$ & $0.8( \pm 0.2)$ & $16.2( \pm 1.2)$ & $1.5( \pm 1.2)$ & bal. \\
\hline
\end{tabular}

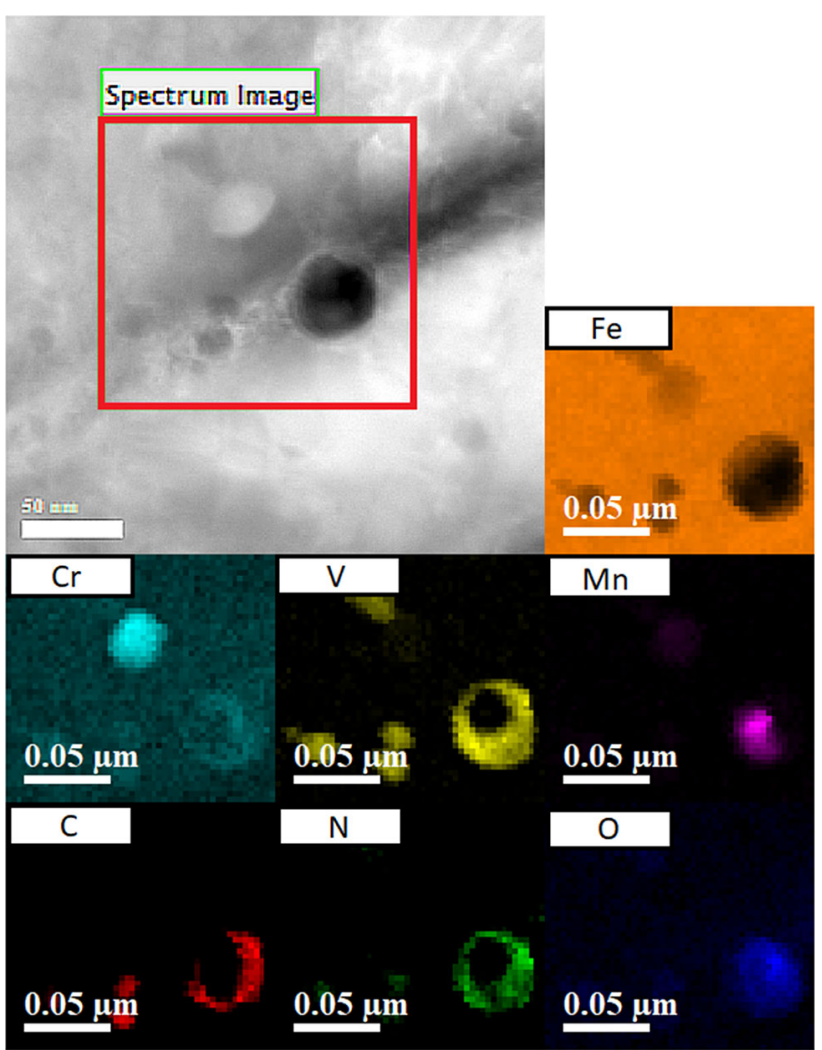

Fig. 13-Survey image and EELS elemental mapping of the quenched sample.

Similar values are achieved by steel produced by conventional methods. ${ }^{[2]}$ The increase in hardness, observed in both tempered samples, can be ascribed to the precipitation of second phases during tempering. The presence of these second phases is confirmed by EELS analysis as shown in Figures 10 and 16. The hardness peak of the directly tempered steel appears to be shifted toward the higher temperatures, as compared to that of quenched and tempered material. The delay in carbide precipitation can be explained considering that segregation regions are likely enriched in $\mathrm{C}$ that has a high solubility in $\gamma$-Fe phase.

\section{CONCLUSIONS}

The effect of heat treatment on microstructure evolution of X38CrMoV5-1 hot-work tool steel processed by L-PBF was investigated and the following conclusions are drawn:

- L-PBF can be used successfully to produce X38CrMoV5-1 parts without cracks.

- The as-built material microstructure is characterized by two main phases arranged in a fine network of cell-like structures where $\gamma$-Fe at cell boundaries encloses the $\alpha^{\prime}$-Fe cores.

- After air quenching, the cellular microstructure is completely lost and it is replaced by a fully martensitic microstructure.

- XRD analysis and TEM images show a martensitic microstructure of the as-built samples as a result of the phase-transformation sequence: Liquid $\rightarrow \delta$-Fe $\rightarrow \gamma$-Fe $\rightarrow \alpha^{\prime}$-Fe, in agreement with the output of the Scheil-Guliver simulation.

- As-built samples feature Mn oxides and V carbonitrides forming core-shell structures, which are not fully dissolved during austenitization.

- During either direct tempering or conventional tempering (after quenching), nano-sized $\mathrm{V}$ and Cr-rich second phases form.

- Both tempered samples, directly from as-built and from quenched condition, show similar hardness values that well match those achieved by X38CrMoV5-1 tool steel produced by conventional methods. The peak in hardness of the specimen 

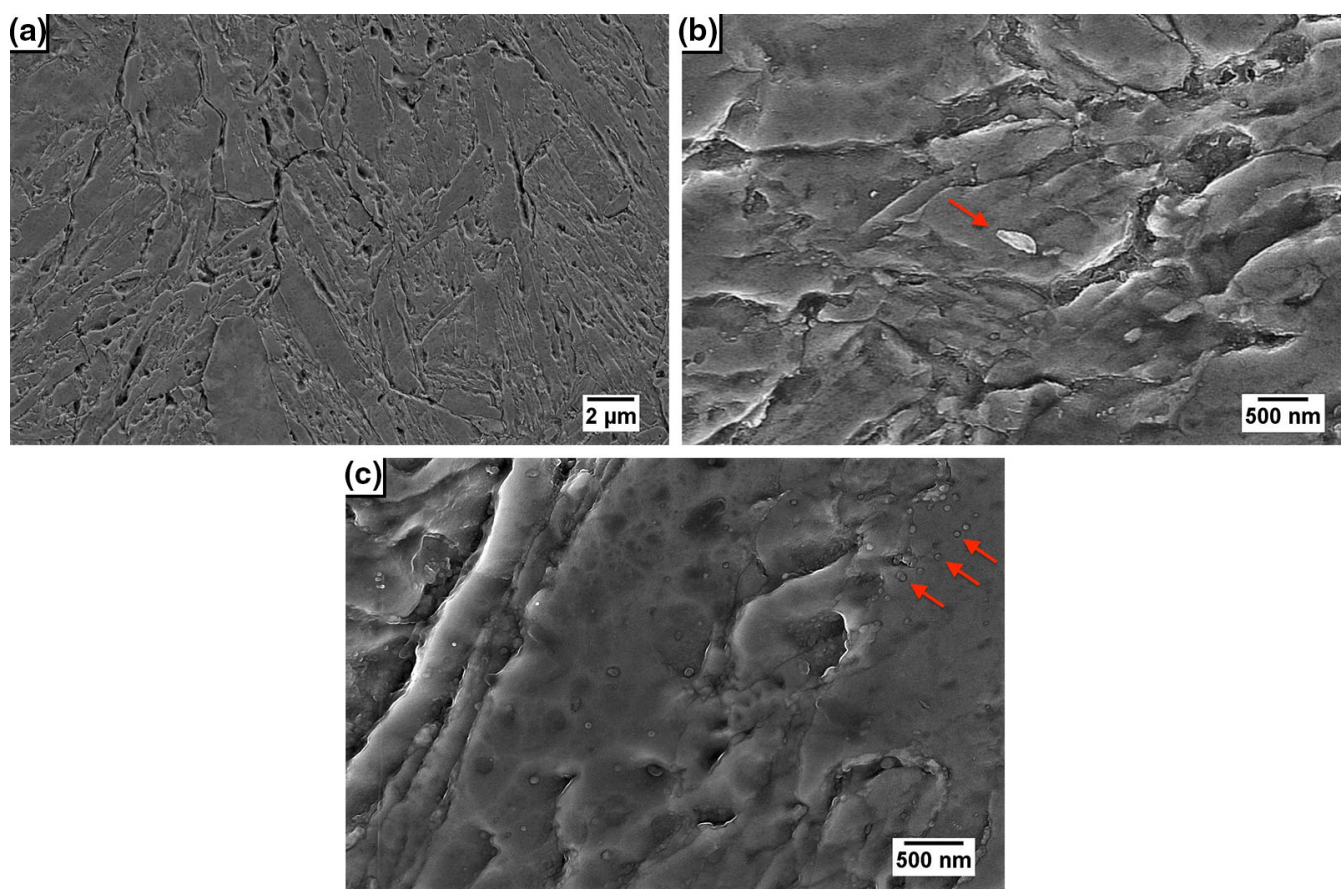

Fig. 14-FE-SEM micrographs of the quenched steel after tempering at $500{ }^{\circ} \mathrm{C}$ at $(a)$ low and $(b, c)$ high magnifications. The red arrows highlight the position of second-phase particles (Color figure online).
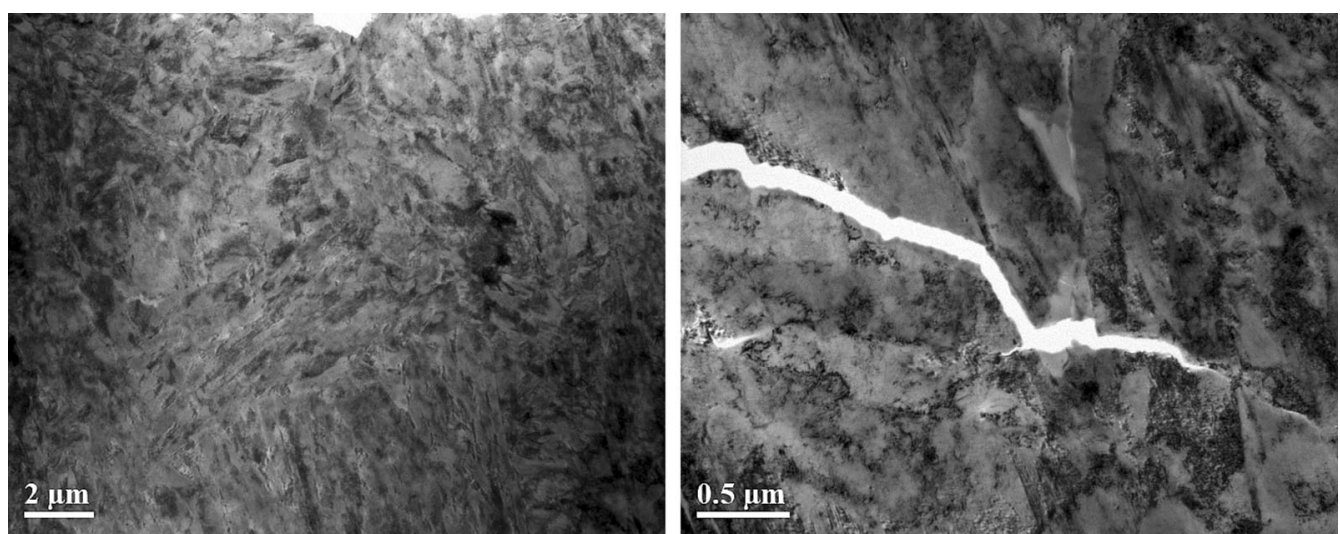

Fig. 15-Bright-field TEM image at low magnification (left) and mid magnification (right) of the quenched and tempered sample. 
Table VII. Chemical Composition in Wt Pet of a Cr-Rich Particle Compared to the Matrix

\begin{tabular}{llccccc}
\hline \multicolumn{7}{c}{ Mass Fraction $($ Wt Pct $)( \pm \sigma)$} \\
\hline Cr & Mo & Si & V & Mn & Fe \\
\hline Particle & $14.9( \pm 1.2)$ & $2.6( \pm 0.7)$ & $1.4( \pm 0.2)$ & $0.2( \pm 0.6)$ & $0.6( \pm 1.1)$ & bal. \\
Matrix & $5.4( \pm 0.9)$ & $2.4( \pm 0.7)$ & $0.5( \pm 0.2)$ & $1.2( \pm 0.6)$ & $0.2( \pm 0.8)$ & bal. \\
\hline
\end{tabular}

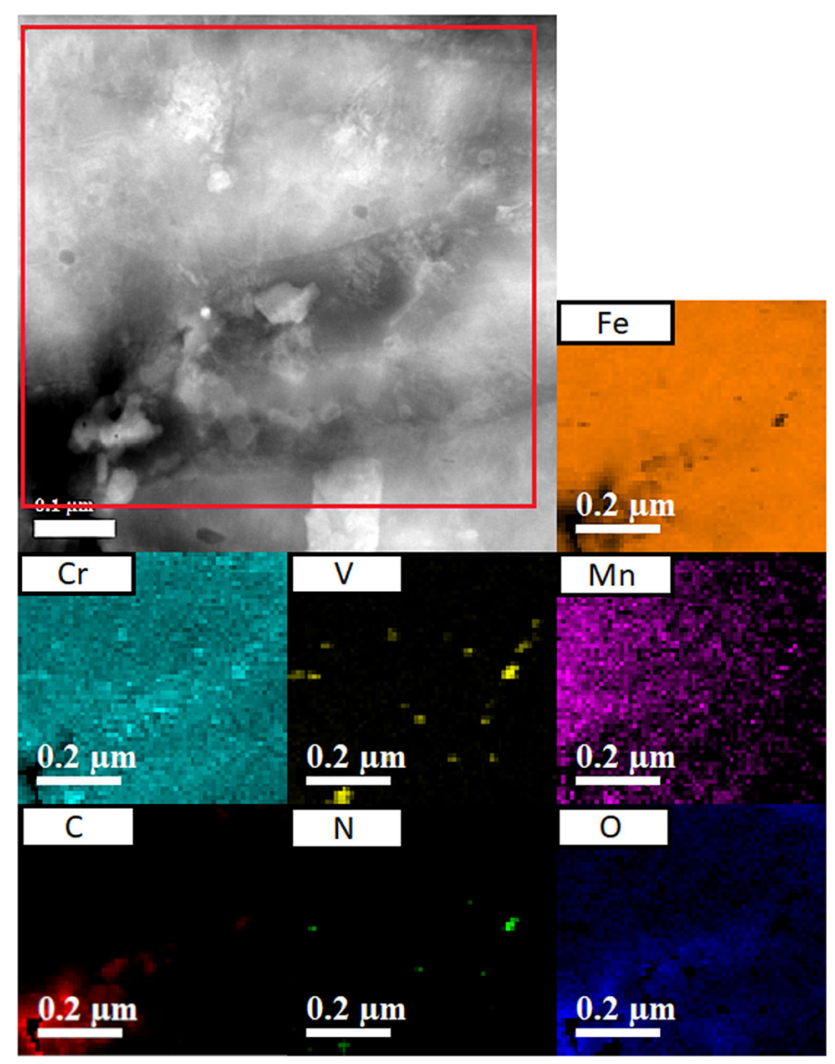

Fig. 16- Survey image and EELS elemental mapping of the quenched and tempered sample.

tempered directly after the L-PBF process is shifted towards higher temperatures $\left(550{ }^{\circ} \mathrm{C}\right)$ as compared to that of quenched and tempered steel $\left(500{ }^{\circ} \mathrm{C}\right)$.

\section{ACKNOWLEDGMENTS}

The present research was supported by the Italian Ministry for Education, University and Research (MIUR) through the project "Department of Excellence LIS4.0" (Integrated Laboratory for Lightweight and Smart Structures).

\section{FUNDING}

Open access funding provided by Politecnico di Milano within the CRUI-CARE Agreement.
Open Access This article is licensed under a Creative Commons Attribution 4.0 International License, which permits use, sharing, adaptation, distribution and reproduction in any medium or format, as long as you give appropriate credit to the original author(s) and the source, provide a link to the Creative Commons licence, and indicate if changes were made. The images or other third party material in this article are included in the article's Creative Commons licence, unless indicated otherwise in a credit line to the material. If material is not included in the article's Creative Commons licence and your intended use is not permitted by statutory regulation or exceeds the permitted use, you will need to obtain permission directly from the copyright holder. To view a copy of this licence, visit http://creativecommons. org $/$ licenses $/$ by $/ 4.0 /$.

\section{REFERENCES}

1. W.E. Frazier: J. Mater. Eng. Perform., 2014, vol. 23, pp. 1917-28.

2. A. Mostafa, I. Picazo Rubio, V. Brailovski, M. Jahazi, and M. Medraj: Metals, 2017, vol. 7, art. no. 196.

3. L. Thijs, K. Kempen, J.-P. Kruth, and J. van Humbeeck: Acta Mater., 2013, vol. 61, pp. 1809-19.

4. R. Casati and M. Vedani: Adv. Eng. Mater., 2018, vol. 21, art. no. 1800406

5. B. Qian, K. Saeidi, L. Kvetková, F. Lofaj, C. Xiao, and Z. Shen: Dent. Mater., 2015, vol. 31, pp. 1435-44.

6. P. Barriobero-Vila, J. Gussone, J. Haubrich, S. Sandlöbes, J.C. Da Silva, P. Cloetens, N. Schell, and G. Requena: Materials, 2017, vol. 10 (3), art. no. 268.

7. R. Casati, J. Lemke, and M. Vedani: J. Mater. Sci. Technol., 2016, vol. 32 , pp. $738-44$.

8. Y. Zhong, L. Liu, S. Wikman, D. Cui, and Z. Shen: J. Nucl. Mater., 2016, vol. 470, pp. 170-78.

9. T. DebRoy, H.L. Wei, J.S. Zuback, T. Mukherjee, J.W. Elmer, J.O. Milewski, A.M. Beese, A. Wilson-Heid, A. De, and W. Zhang: Prog. Mater. Sci., 2018, vol. 92, pp. 112-24.

10. M. Mazur, P. Brincat, M. Leary, and M. Brandt: Int. J. Adv. Manuf. Technol., 2017, vol. 93, pp. 881-900.

11. C. Højerslev: Tool steels, Roskilde: Risø National Laboratory, Denmark, January 2001.

12. G. Roberts, G. Krauss, R. Kennedy: Tool Steels, 5th ed., ASM International, 1998.

13. Y. Bai, Y. Yang, D. Wang, and M. Zhang: Mater. Sci. Eng. A, 2017, vol. 703, pp. 116-23.

14. R. Casati, J.N. Lemke, A. Tuissi, and M. Vedani: Metals, 2016, vol. 6 , pp. $218-28$.

15. K. Kempen, B. Vrancken, S. Buls, L. Thijs, J. Van Humbeeck, and J.-P. Kruth: J. Manuf. Sci. Eng., 2014, vol. 136, art. no. 061026.

16. Z.H. Liu, D.Q. Zhang, C.K. Chua, and K.F. Leong: Mater. Charact., 2013, vol. 84, pp. 72-80.

17. J. Krell, A. Röttger, K. Geenen, and W. Theisen: J. Mater. Process. Technol., 2018, vol. 255, pp. 679-88.

18. F. Deirmina, N. Peghini, B. AlMangour, D. Grzesiak, and M. Pellizzari: Mater. Sci. Eng. A, 2019, vol. 753, pp. 109-21. 
19. J. Safka, M. Ackermann, and L. Volesky: J. Phys. Conf. Ser., 2016, vol. 709, art. no. 012004.

20. R. Mertens, B. Vrancken, N. Holmstock, Y. Kinds, J.-P. Kruth, and J. van Humbeeck: Phys. Procedia, 2016, vol. 83, pp. 882-90.

21. R. Casati, M. Coduri, N. Lecis, C. Andrianopoli, and M. Vedani: Mater. Charact., 2018, vol. 137, pp. 50-57.

22. M. Åsberg, G. Fredriksson, S. Hatami, W. Fredriksson, and P. Krakhmalev: Mater. Sci. Eng. A, 2019, vol. 742, pp. 584-89.

23. B. AlMangour, D. Grzesiak, and J.M. Yang: J. Mater. Process. Technol., 2017, vol. 244, pp. 344-53.

24. ASTM international, Standard specification for Tool Steels Alloy, Designation: A681-08.

25. A. Altomare, N. Corriero, C. Cuocci, A. Falcicchio, A. Moliterni, and R. Rizzi: J. Appl. Crystallogr., 2015, vol. 48, pp. 598-603.
26. J. Rodriguez-Carvajal: Satellite meeting on powder diffraction of the XV congress of the IUCr, p. 127, Toulouse, France, 1990.

27. J.J. Yan, D.L. Zheng, H.X. Li, X. Jia, J.F. Sun, Y.L. Li, M. Qian, and M. Ya: J. Mater. Sci., 2017, vol. 52, pp. 12476-485.

28. P. Bajaj, A. Hariharan, A. Kini, P. Kürnsteiner, D. Raabe, and E.A. Jägle: Mater. Sci. Eng. A, 2020, vol. 772, art. no. 138633

29. S. Raju, B.J. Ganesh, and A. Banerjee: Mater. Sci. Eng. A, 2007, vol. 465 , pp. $29-37$

30. B. Engel and D.L. Bourell: Rapid Prototyp. J., 2000, vol. 6, pp. $97-106$.

31. S. Das: Adv. Eng. Mater., 2003, vol. 5, pp. 701-11.

Publisher's Note Springer Nature remains neutral with regard to jurisdictional claims in published maps and institutional affiliations. 